\title{
Shareholder Primacy and Worker Prosperity: A Broken Link
}

\section{Lenore Palladino*}

\section{INTRODUCTION}

The increasing financialization of America's large public companies has profoundly affected labor markets. Wages are stagnant, income inequality has grown, and corporate America is no longer a provider of stable employment for middle-class workers. Common explanations include globalization, the rising power of the financial sector itself, the decline of trade union power, and skill-biased technical change. However, changes in how corporations earn profits, and how they use those profitsthe two strands of behavior that I call corporate financialization - are key drivers of rising economic insecurity, and require further consideration.

Rising corporate profits - driven in large part by increasing market concentration-have been disproportionately captured by the wealthy rather than reinvested in the firm. ${ }^{1}$ I define corporate financialization as the mechanism for such capture, specifically through the rise of two kinds of financial activities within firms. First, corporate firms are holding a rising proportion of financial assets, and consequently, earn an increasing proportion of total profit from such assets, versus the profit that they earn from their normal business activity. ${ }^{2}$ Second, profits are increasingly used to drive up rising short-term share prices rather than to invest in labor or capital. $^{3}$ These changes mean a higher proportion of corporate cash goes to shareholders and the purchasing of financial assets, leaving less for workers and productive investment. ${ }^{4}$ This leads to the economic puzzle

* Lenore Palladino is Senior Economist and Policy Counsel at the Roosevelt Institute and a Lecturer at Smith College. Palladino is Of Counsel at the Law Firm of Jason Wiener p.c. Palladino earned her Ph.D. from the New School University and J.D. from Fordham Law School.

1. See Germán Gutiérrez \& Thomas Philippon, Investment-less Growth: An Empirical Investigation 1-2, 6 (Nat'l Bureau of Econ. Research, Working Paper No. 22897, 2017) [hereinafter Investment-less Growth]; J.W. MASON, DisGorge tHE CASH: THE Disconnect BetweEN CORPORATE BORROWING AND INVESTMENT 1-4 (Roosevelt Inst., 2015), rooseveltinstitute.org/wpcontent/uploads/2015/09/Disgorge-the-Cash.pdf.

2. Greta R. KripPNer, CAPitalizing ON CRisis: The Political Origins of the Rise of FINANCE loc. 715-17 (2012) (ebook).

3. See MASON, supra note 1 , at 3, 5 .

4. See id. at 15 . 
we see today: record corporate profits and share prices coupled with low corporate investment and wage growth.

Since firms are made up of different constituencies (e.g. employees, executives, and shareholders) and there are multiple ways for firms to use profits (e.g. investment, increased compensation, or shareholder payouts) - a rising proportion of profit flowing to one set of stakeholders or uses will result in a decline in what is available for the others. The rise in firms' savings and holding of financial assets has meant firms are net lenders rather than net borrowers in a macroeconomic sense, undermining the traditional notion that the financial sector exists to support corporate investment. ${ }^{5}$ The set of public policies that have incentivized financial asset-holding and increasing financial flows to shareholders must be taken on directly in order to improve the economic security of the American people.

In this paper, I focus on financialization in the nonfinancial corporate (NFC) sector of the economy, which has received less attention than the dynamic of the rising financial sector. First, I describe the current state of America's public corporations and labor markets, and the legal and regulatory changes that drove shifts in corporate behavior. Next, I examine the two corporate financialization flows: first, the rise of financial profits versus profits earned off of the sales of goods and services; second, the rise of short-termism ${ }^{6}$ and shareholder maximization. In each section, I will review some of the literature that defines these phenomena and focus on research that demonstrates their impact on wages, employment, and the fissured workplace.

Numerous researchers document the rise of financial profit-making within NFCs and examine its relationship with declining productive investment and declining labor market outcomes. Others focus on the increase of capital market pressures and the ethos of shareholder value maximization. Some researchers define corporate financialization as the rising ratio of financial profit earned off of financial assets relative to business profits earned from the regular trade of the corporation. ${ }^{7}$ Other

5. See generally Peter Chen, Loukas Karabarbounis \& Brent Neiman, The Global Rise of Corporate Saving, 89 J. MONETARY ECON. 1 (2017) (studying the behavior of corporate savings and discussing its relationship to the global decline in the labor share, the accumulation of corporate cash stocks, and the increased propensity for equity buybacks).

6. Short-termism is a "corporate philosophy that prioritizes immediate increases in share price and payouts at the expense of long-term business investment and growth." NELL ABERNATHY, MiKE Konczal \& Kathryn Milani, Untamed: How to Check Corporate, Financial, and MONOPOLY POWER 60 (Roosevelt Inst., 2016), rooseveltinstitute.org/wp-content/uploads/2016 /06/Untamed-Final-5.10.17.pdf.

7. See Ken-Hou Lin \& Donald Tomaskovic-Devey, Financialization and U.S. Income 
researchers focus on the increase in unproductive stock repurchases and dividend payments as a primary measure of the rise of shareholder maximization as the modus operandi of firms. ${ }^{8}$ This paper combines the two lenses on corporate activity to follow the flows of profits into-and out of - the firm.

"Financial assets" in the NFC context refers to the holdings of cash and short-term investments, current receivables, advances, and a miscellaneous category of "other" financial assets. Financial asset holdings are not trivial: The Financial Times has documented how, in 2015, NFC financial holdings topped $\$ 2$ trillion for the first time, outstripping the asset holdings of traditional Wall Street asset managers. ${ }^{9}$ Just thirty US companies have portfolios of cash, securities, and investments worth, together, more than $\$ 1.2$ trillion; holdings of corporate debt and commercial paper have reached a record $\$ 432$ billion, as companies, for tax reasons, have avoided repatriating cash and instead looked for riskier investment opportunities. ${ }^{10}$ The Financial Times noted that the fact that NFCs are "pumping excess cash into bonds reinforces the depressing fact that many companies don't see attractive investment opportunities in their business lines, helping explain the lack of stronger economic activity and mediocre wage gains for workers in recent years."11

Before focusing solely on the process of financialization within NFCs, it is useful to define the term "financialization" as it pertains to the entire economy. ${ }^{12}$ The term is commonly used to describe the rising share of

Inequality, 1970-2008, 118 AM. J. Soc. 1284, 1286 (2013); Greta R. Krippner, The Financialization of the American Economy, 3 Socio-ECon. Rev. 173, 174 (2005); Leila E. Davis, Financialization and the Nonfinancial Corporation: An Investigation of Firm-Level Investment Behavior in the U.S., 197120112 (Econ. Dep't Working Paper Series, Working Paper No. 2013-08, 2013) [hereinafter Nonfinancial Corporation], https://scholarworks.umass.edu/cgi/viewcontent.cgi?article $=1160 \&$ context=econ_workingpaper .

8. See MASON, supra note 1, at 2-3 (conducting an empirical analysis on the shift in the relationship between corporate borrowing and cash flow on the one hand and investment and shareholder payouts on the other hand, before and after 1980); William Lazonick, Profits Without Prosperity, HARV. BUS. REV. (Sept. 2014) [hereinafter Profits Without Prosperity], https://hbr.org/2014/09/profits-without-prosperity (describing the rise of stock buybacks and their role in corporate investment decisions).

9. See Eric Platt, Alexandra Scaggs \& Nicole Bullock, How Apple and Co Became Some of America's Largest Debt Collectors, FIN. TIMES (Sept. 15, 2017) [hereinafter Largest Debt Collectors], https://www.ft.com/content/27ab1da0-99f6-11e7-b83c-9588e51488a0.

10. Id.

11. See Michael Mackenzie, Corporate Bondholders Heighten Market Risk, FIN. TIMES (Sept. 14, 2017), https://www.ft.com/content/b90f541e-985c-11e7-a652-cde3f882dd7b.

12. For a full discussion of the shifts in the financial sector and the impact of financialization on American culture, see generally Mike KonCZAL \& NELl ABERNATHY, DEFINING FINANCIALIZATION (Roosevelt Inst., 2015), http://rooseveltinstitute.org/wp-content/uploads/2015/10/Defining _ Financialization_Web.pdf. 
profit accruing to the financial sector (as opposed to nonfinancial corporations) and the shift in the culture toward a market orientation. ${ }^{13}$ Nell Abernathy and Mike Konczal define financialization as encompassing four core elements: savings, power, wealth, and society. ${ }^{14}$ They further define it as "the growth of the financial sector, its increased power over the real economy, the explosion in the power of wealth, and the reduction of all of society to the realm of finance." 15 Gerald Epstein describes financialization as "the increasing role of financial motives, financial markets, financial actors, and financial institutions in the operation of the domestic and international economies." ${ }^{16}$ Gerald Epstein and Arjun Jayadev examined the rentier share of national income - that is, the rising profits of financial firms plus the interest income generated by nonfinancial firms and households - to describe the rise of the financial sector's power in the economy. ${ }^{17}$ Other authors link financialization to broad macroeconomic trends of declining growth and compare the structural forces of financialization and neoliberalism. ${ }^{18}$

Though corporations are currently driving economic inequality, it is important to remember that corporations can, in theory, be creators of economic prosperity. William Lazonick outlines the "theory of innovative enterprise," in which innovation drives the creation of higher-quality products at lower unit costs, benefitting consumers. ${ }^{19}$ Innovation stems

13. See Gerald Davis, Managed by the Markets: How Finance Re-Shaped America 1 (2009); Thomas I. Palley, Financialization: What It Is and Why It Matters (Levy Econ. Inst., Working Paper No. 525, 2007), http://www.levyinstitute.org/pubs/wp_525.pdf.; see generally GERALD A. EPSTEIN, FINANCIALIZATION AND THE WORLD ECONOMY (Gerald A. Epstein ed., 2005) [hereinafter WORLD ECONOMY].

14. KONCZAL \& ABERNATHY, supra note 12, at 4.

15. Id.

16. Gerald Epstein, Financialization: There's Something Happening Here 5 (Pol. Econ. Res. Inst., Working Paper No. 394, 2015), https://www.peri.umass.edu/publication/item/684financialization-there-s-something-happening-here (citation omitted).

17. See generally Arjun Jayadev \& Gerald Epstein, The Correlates of Rentier Returns in OECD Countries (Poli. Econ. Res. Inst., Working Paper No. 123, 2007), https://scholarworks.umass.edu/cgi/viewcontent.cgi?article=1098\&context=peri_workingpapers.

18. Palley, supra note 13 , at 6 . Thomas Palley argues that financialization may be culpable for the growth of income inequality in the United States, and that the "defining feature of financialization in the U.S. has been the increase in the volume of debt." $I d$. Palley argues further that financialization is a particular form of neoliberalism. Id. at 24. "That means neoliberalism is the driving force behind financialization and the latter cannot be understood without an understanding of the former." THOMAS I. PALlEy, FinANCIALIZATION: THE ECONOMics OF FinANCE CAPITAL DOMINATION 1 (2013).

19. William Lazonick, The Theory of Innovative Enterprise: A Foundation of Economic Analysis 4-16 (The Acad. Indus. Res. Network, Working Paper No. 13-0201, 2013), http://www.theairnet.org/v3/backbone/uploads/2015/08/Lazonick.TIE-Foundations_AIR-

WP13.0201.pdf. Lazonick defines innovation as the generation of higher-quality and/or lower-cost products at prevailing input costs, which increases per capital output. See id. However, since 
from a "retain-and-reinvest" model of corporate resource allocation, in which corporations retain profit and crucially invest in the productivity of workers by paying stable wages and rewarding skill growth and longevity in order to increase the innovation that they, the corporations, are able to produce and thus the profits they are able to earn. ${ }^{20}$ It is due to a reliance on profits earned from improving productivity that workers are able to bargain for an increased share of profits in the form of higher wages and benefits. ${ }^{21}$ As will be explored below, America's firms have moved to the other end of the spectrum from this idealized version of corporate purpose, making it essential to reverse the incentives that drive corporate behavior.

\section{THE DECLINE OF THE INNOVATION-FocUSED PUBLIC CORPORATION}

The postwar era saw the rise of the corporation and the linkage of stable corporate employment with basic family needs such as a stable income, health care, and retirement (though the availability of such employment was deeply stratified by race and gender). ${ }^{22}$ Firms depended on a steady workforce, and unions were able to make significant gains for their members, while hired managers came to wield significant authority over the decisions of the firms that employed them. ${ }^{23}$ Starting in the 1980 s, there have been significant shifts in the structure of large corporations and a concurrent long-term decline in employment security for workers. ${ }^{24}$ Though there are exceptions, the major transition that took place in the 1980s was from a corporate model in which success ultimately rested on the growth of sales to one in which maximizing returns for shareholders was the focus. ${ }^{25}$

Beginning in the late twentieth century, workers became the largest cost to cut in pursuit of strong capital market valuation. ${ }^{26}$ Gerald Davis

innovation is a social process, there is not a prior reason why gains from innovative enterprise will be distributed equitably.

20. Id. Zeynap Ton describes a similar model to Lazonick. See generally ZEYNEP TON, THE GoOd Jobs Strategy: How the SMARTEST COMPANIES INVEST IN EMPLOYEES TO LOWER COSTS AND BoOST PROFITS (2014) (examining specific firms and how their investment in their workforce results in higher customer satisfaction, profit, and market share).

21. See generally Rick WARTZMAn, THE END OF LoyAlty: THE RisE AND FALL OF GOOD JOBS IN AMERICA (2017) (describing the history of employee bargaining power in the 20th century).

22. See generally GERALD F. DAVIS, THE VANISHING AMERICAN CORPORATION: NAVIGATING THE HAZARDS OF A NEW ECONOMY (2016) [hereinafter VANISHING AMERICAN CORPORATION] (describing, in full, the shifts in public corporations over the last hundred years).

23. Id. at $22-23,39,41-42$.

24. Id. at 53, 57-67.

25. Id. at 59-61.

26. See DAVID WeIl, The Fissured WorkPlace: Why Work Became So Bad for So Many AND WHAT CAN BE DONE TO IMPROVE IT 10-12 (2014). 
describes how highly conglomerated firms that had been undervalued by the stock market were broken up through a wave of hostile takeovers in the 1980s. ${ }^{27}$ As firms became more responsive to capital market pressures and takeover threats, the labor accords of the postwar era became subject to rising cost scrutiny. ${ }^{28}$ By the 1990 s, maximizing shareholder value had become the dominant mode for public corporations, driven by legal and regulatory shifts under the Reagan administration. ${ }^{29}$ Leading firms (e.g. Nike) focused on brand value over production and spun off to global suppliers, enabled by the rise of information and communication technologies (ICTs). ${ }^{30}$ Large-scale layoffs and rising benefits insecurity ensued-American mainstays like Sara Lee went from 154,000 to 10,000 employees in ten years, and the computer and electronics industry as a whole lost 750,000 jobs. ${ }^{31}$ Since creating shareholder value was at odds with long-term, well-paid employment, employee cost-cutting became the norm and the labor market as a whole was destabilized. ${ }^{32}$

David Weil documents a substantially similar process by focusing on the fissured workplace. ${ }^{33}$ He shows that as large corporations increasingly focused on core competencies in response to investor pressure to raise share prices, they moved a percentage of their workforce out of direct employment through subcontracting, outsourcing, or franchising. ${ }^{34}$ Nonprofessional workers were no longer considered central to firm productivity - rather, firm profit required keeping overall labor costs as cheap as possible and getting rid of all the ancillary costs of direct employment. ${ }^{35}$ Pressure from the financial markets caused companies to shed increasing numbers of noncore employees. ${ }^{36}$ This reduced the ability of workers to claim a share of any increased profit made by leading firms. ${ }^{37}$ Fundamentally, labor was shifted from "a wage setting problem into a contracting decision." 38

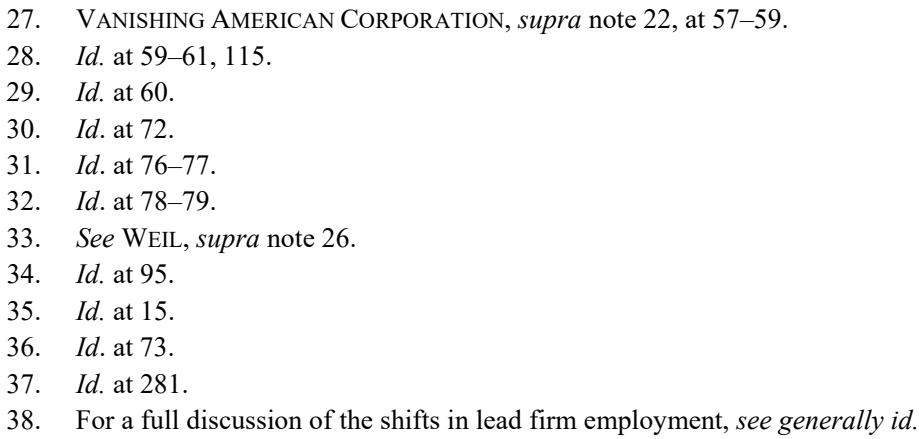




\section{THE RISE OF CORPORATE FINANCIALIZATION}

The changes in corporate behavior have led to an emphasis within firms on financial assets and shareholder value. These shifts have happened within the context of rising corporate profits and stagnant wages. To analyze the impact of this shift on employees specifically, it is important to first measure increasing corporate financialization directly. Two types of measurements are important: first, the proportional rise of financial assets and income earned off of such assets, relative to profit earned from selling goods and services; second, the relative proportion of overall firm profit flowing to payouts to shareholders.

Peter Chen, Loukas Karabarbounis, and Brent Neiman document two key shifts in global corporate behavior that show the rise of corporate financialization across industries and countries. ${ }^{39}$ First, corporate savings rose as a proportion of global savings, driven by increasing corporate profits; ${ }^{40}$ such savings become, in a macroeconomic sense, the funds available for the rest of the economy to borrow, and corporations are now net lenders to the rest of the economy. ${ }^{41}$ Corporate profits are allocated to payments to labor, capital, taxes, and savings, so, since labor's share declined and taxes and dividends remained steady, corporate savings ineluctably rose. ${ }^{42}$ Second, they show how firms use this increase in savings, the options being to reinvest savings in productive investment or accumulate cash or other financial assets (one of the first indicators of increased financialization), repay debt, or increase share repurchases (the second major indicator of increased financialization). ${ }^{43}$ They document that productive investment did not keep pace with rising corporate savings and that all of the other uses of increased savings grew. ${ }^{44}$ "Given that dividend payments and investment did not increase much as a share of value added [profits], firms used part of the increased flow of savings to repurchase their shares and part of it to accumulate cash and other types of financial assets." 45

In the rest of this section, I discuss the literature that focus the analysis on the United States.

\footnotetext{
39. See generally Chen, Karabarbounis \& Neiman, supra note 5.

40. Id. at 2. Elsewhere in their analysis, the authors discuss the drivers of increased corporate profits: a declining real interest rate, the price of investment goods, and declining corporate taxes. Id. at 14. They do not discuss declining bargaining power of labor.

41. $\quad I d$. at 2 .

42. Id. at $12-14$.

43. $I d$.

44. Id.

45. Id. at 18 .
} 


\section{A. Rising Financial Income within Nonfinancial Corporations}

The first way to measure corporate financialization is to look at the increase in income that firms make from financial assets and rising financial asset-holding. Greta Krippner presents evidence for a shifting "pattern of accumulation in which profits accrue primarily through financial channels rather than through trade and commodity production. . . '[f]inancial' here refers to activities relating to the provision (or transfer) of liquid capital in expectation of future interest, dividends, or capital gains." 46 In other words, the "lens" she uses to analyze changes in American business looks at how profits are generated, rather than how employment has changed or the type of output has shifted. ${ }^{47}$

In her study, Krippner measured the increasing ratio of portfolio income-income earned off of financial assets - to revenue from productive activities, looking at the total earnings accruing to NFCs from interest, ${ }^{48}$ dividends, and realized capital gains on financial investments, and measuring revenue using corporate cash flow (profits plus depreciation allowances) ${ }^{49}$ She finds that the ratio began to climb in the 1970s and peaked in the 1980s at a level that was five times the ratio typical in the preceding decades. ${ }^{50}$ Notably, in the 1970 s it was manufacturing firms that led the shift to relying on an increasing share of profit from financial activity. ${ }^{51}$ Krippner also found that a rise in interest income largely drove the surge in portfolio income, while capital gains and dividends held steady, demonstrating that a growing stock market cannot fully explain NFC financialization. ${ }^{52}$

Ken-Hou Lin's study shows how firms shifted into holding a rising proportion of financial assets. ${ }^{53}$ Specifically, in the 1980s and 1990s, ownership of financial assets varied with the business cycle, but since the

\footnotetext{
46. Krippner, supra note 7, at 174-75 (internal citations omitted).

47. Krippner characterizes this as an activity-centric (versus an accumulation-centric) view of the economy. Id. She compares the "pictures" of the economy that emerge from the different viewpoints, showing that examining shifts in employment and output do not properly reveal the rise of financial income within "real economy" firms. Id.

48. This is the use of corporate cash in the financial sector, loaning it out as commercial paper to earn a return.

49. Krippner, supra note 7, at 182-86.

50. Id. at 184 .

51. Lin \& Tomaskovic-Devey, supra note 7, at 1286.

52. Krippner, supra note 7, at 186.

53. See generally Ken-Hou Lin, The Rise of Finance and Firm Employment Dynamics, 27 ORG. SCI. 972 (2017) (discussing the institutional changes leading to firms holding a rising share of financial assets).
} 
2000s there has been a steady rise in such ownership. ${ }^{54}$ This ownership is highly concentrated in large firms: Just thirty United States companies have together amassed holdings of more than $\$ 1.2$ trillion worth of cash, securities, and financial investments. ${ }^{55}$ Roughly $70 \%$ are held overseascrucially, financial investment can be conducted without bringing the profit "home" to the United States, whereas productive investments require such repatriation and payment of United States corporate taxes. ${ }^{56}$

Greta Krippner posits that rising financial asset-holding was initially driven by the high-interest-rate environment of the 1980s, when it was a bad time to be a borrower and a good time to be a lender. ${ }^{57}$ Corporate cash was directed toward higher-yield short-term financial assets rather than borrowing for investment purposes at extraordinarily high interest rates. ${ }^{58}$ As will be explored in the next section, the push to increase short-term returns rose with the threat of takeovers driven by newly emboldened activist investors. ${ }^{59}$ In the current era, as interest rates have stayed historically low, for large firms at least, financial asset ownership may still provide a higher return in the short term than putting corporate cash to work where the gains require a long-term focus. ${ }^{60}$ The challenge is to reorient public policy so that it rewards investment in long-term, sustainable productivity, rather than incentivizing short-term gains from financial asset-holding.

United States corporate tax policy has also driven the rise of financial asset-holding. Prior to the passage of the Tax Cuts and Jobs Act, firms holding cash overseas to avoid United States corporate tax rates could not repatriate the cash to invest in capital assets or employees in the United States, but they could use the cash to buy financial assets that they then continue to hold on the books of subsidiaries abroad. ${ }^{61}$ Until 2018, the United States corporate tax rate was relatively high, but the tax raised less revenue as a share of national income than comparable taxes did in other advanced economies. ${ }^{62}$ The United States corporate tax code did not, until

54. Id. at 974 .

55. Largest Debt Collectors, supra note 9.

56. See Eric Platt, Nicole Bullock, \& Alexandra Scaggs, U.S. Companies Transformed into $800 \mathrm{lb}$ Gorilla in Bond Market, FIN. TIMES (Sept. 12, 2017), https://www.ft.com/content/46027dd28f6c-11e7-9084-d0c17942ba93.

57. Krippner, supra note 7 , at 186.

58. Id. at 183.

59. See infra Section II.B.

60. Largest Debt Collectors, supra note 9.

61. $I d$.

62. See Kimberly A. Clausing, Strengthening the Indispensable U.S. Corporate Tax 6, 8, 11, 28 (Wash Ctr. for Equitable Growth, 2016). 
the recent passage of the Tax Cuts and Jobs Act 2017, ${ }^{63}$ tax foreign income until it was repatriated, decreasing the incentive to invest in the United States and making more attractive the incentive to invest in financial assets with otherwise-idle cash stashed abroad. ${ }^{64}$

How debt is treated in corporate tax policy has also driven the rise of corporate financialization. Financial and nonfinancial corporations have a tax-driven incentive to fund operations through debt rather than equity, which decreases their ability to sustainably absorb losses. ${ }^{65}$ Firms are able to take a tax deduction for interest payments on their debt but not for the returns they pay out on equity, namely dividend and capital gains payments to shareholders. ${ }^{66}$ The fact that payments on equity cannot be deducted when computing corporate taxable income, but interest payments on debt can, leads to an overuse of leverage by firms. ${ }^{67}$ This pro-debt bias affects nonfinancial and financial corporations, but the cumulative impact of increased leverage is more significant in the financial sector. ${ }^{68}$ During the financial crisis, firms were vastly indebtedLehman Brothers and Bear Stearns had less than $4 \%$ of their value in equity $^{69}$ - and took on additional risk by using instruments like hybrid securities, which counted as debt for tax purposes but were considered equity for regulatory purposes. ${ }^{70}$

\section{B. The Shift to Shareholder Value Maximization}

A robust literature ${ }^{71}$ documents the second strand of corporate financialization: the dominant ideology of shareholder value maximization and related shifts in executive pay. As firms were driven by pressure from shareholders to maximize profits and share value in order to fund higher dividends and returns from selling shares, rising share price

\footnotetext{
63. Tax Cuts and Jobs Act, Pub. L. No. 115-97, 131 Stat. 2054 (2017).

64. Clausing, supra note 62, at 8, 29.

65. Robert C. Pozen \& Lucas W. Goodman, Capping the Deductibility of Corporate Interest Expense, 137 TAX NOTES 1207, 1222 (2012), https://corpgov.law.harvard.edu/wp-content/uploads/ 2013/01/Capping-the-Deductibility-of-Corporate-Interest-Expense.pdf.

66. Id.

67. Id.

68. Mark J. Roe \& Michael Tröge, Taxing Banks Properly: The Next Regulatory Frontier 3 (2016), web.law.columbia.edu/sites/default/files/microsites/law-economics-studies/taxingbanksprop erly_feb_20_2016_v5.2.pdf.

69. Id. at 6 .

70. Id.

71. A review of the literature documenting this rise is beyond the scope of this paper. See, e.g., Profits Without Prosperity, supra note 8; VANISHING AMERICAN CORPORATION, supra note 22; and WORLD ECONOMY, supra note 13.
} 
became the core concern of firm management, which moved away from the previous era of "managerial capitalism." " Under managerial capitalism, directors saw themselves as responsible for a broader set of stakeholders, including but not limited to shareholders. ${ }^{73}$ Share price was one core metric, but revenue and profit, market share, and long-term investments also mattered to firm performance. The rise of institutional investors and ownership by large financial institutions, such as private equity funds, drove the transition away from long-term stock holding and toward short-term stock trading. This focus on short-term outcomes distinguishes shareholders from sharesellers, as the focus on short-term gain hurts the very kinds of productive investment that can provide for longer-term sustainable growth of firm output. ${ }^{74}$

The shareholder primacy model taught that corporate executives served as agents of the corporate owners - shareholders - and executives should therefore maximize value for shareholders, focusing on the key metric of the share price. ${ }^{75}$ This thinking led to "dramatic shifts in U.S. corporate law and practice," in the form of changes to corporate governance rules, executive compensation norms - principally the rise of stock-based pay-and federal securities laws. ${ }^{76}$ The ascendance of the ideology can be traced to Milton Friedman's 1970 essay in the New York Times arguing for shareholder primacy. ${ }^{77}$ The article was followed up by Michael Jensen and William Meckling's 1976 "Theory of the Firm," which started from an assumption that shareholders own corporations and therefore are entitled to residual profits. ${ }^{78}$ Shareholder primacy succeeded in part because corporate executives became shareholders through the increasingly popular practice of paying executives through shares and

\footnotetext{
72. See generally WARTZMAN, supra note 21 .

73. Id.

74. William Lazonick, Matt Hopkins \& Ken Jacobson, The Burger Buyback King: McDonald's Stock-Price Manipulation Makes Most Americans Worse Off 4 (The Acad. Indus. Res. Network, Working Paper No. 15-05/01, 2015) [hereinafter Burger Buyback] http://www.theairnet.org/v3/ backbone/uploads/2015/05/Lazonick.Hopkins.Jacobson_Burger.Buyback.King_AIRWP15.0501.pdf.

75. Lynn A. Stout, The Shareholder Value Myth 4 (Cornell Law Faculty Publ'n No. 771, 2013), $\mathrm{http}: / /$ scholarship.law.cornell.edu/cgi/viewcontent.cgi?article=2311\&context=facpub. (discussing the rise of the ideology of shareholder primacy and its critical flaws as a matter of law).

76. Id. at 1

77. See Milton Friedman, The Social Responsibility of Business is to Increase its Profits, N.Y. TiMES (Sept. 13, 1970), https://timesmachine.nytimes.com/timesmachine/1970/09/13/223535562.pdf.

78. Michael C. Jensen \& William H. Meckling, Theory of the Firm: Managerial Behavior, Agency Costs And Ownership Structure, 3 J. FIn. ECON. 305, 309 (1976).
} 
because of the loophole that allowed stock-based pay to continue to be deducted by corporations even when it was over $\$ 1$ million. ${ }^{79}$

Lynn Stout in The Shareholder Value Myth questions whether shareholder primacy has any basis in United States corporate law. ${ }^{80}$ She distinguishes the idea that shareholders "own" corporations from the legal construct that corporations in fact own themselves, while what shareholders own are shares in the legal entity known as the corporation that give shareholders limited legal rights. Further, "in this regard, shareholders stand on equal footing with the corporation's bondholders, suppliers, and employees, all of whom also enter contracts with the firm that give them limited legal rights." ${ }^{\prime \prime}$ Another version of shareholder primacy says that shareholders are the "residual claimants" of the firm's profits, other stakeholders having fixed contractual claims. ${ }^{82}$ Stout shows that this claim only holds when firms are in bankruptcy, since otherwise corporations are in fact their own residual claimant, entitled to keep their profits for use at directors' discretion. ${ }^{83}$ However, despite the legal issues with the shareholder primacy argument, it remains the dominant model in corporate practice. ${ }^{84}$

\section{The Rise of Stock Buybacks}

The rise of shareholder primacy has caused exponential growth in the corporate practice of buying back shares of their own stock on the open market, increasing their share price (as fewer shares remain) without improving their product or finding new customers. ${ }^{85}$ This has the direct consequence of reducing the earnings that are retained within the firm. Before the 1970s, American corporations paid out 50\% of profits to shareholders and retained the rest for investment. ${ }^{86}$ Now, shareholder payments are $90 \%$ of reported profits. ${ }^{87}$ Buybacks are a speculative

79. Jena McGregor, This Tax Loophole Led to Massive CEO Pay Packages. Why Eliminating it isn't Likely to Rein Them in, WASH. POST (Nov. 22, 2017), https://www.washingtonpost.com/ news/on-leadership/wp/2017/11/22/this-tax-loophole-led-to-massive-ceo-pay-packages-why-

eliminating-it-isnt-likely-to-rein-them-in/?utm_term=.46bce4eab345. Corporate tax law otherwise does not allow for corporations to deduct executive pay over $\$ 1$ million; the "performance-based loophole" was in existence until the 2018 tax law reforms. Id.

80. See generally Stout, supra note 75.

81. Id. at 4 .

82. Id. at 3

83. Id.

84. Id. at 2 .

85. Profits Without Prosperity, supra note 8, at 2.

86. MASON, supra note 1.

87. Id. 
mechanism that do not provide new productive capital to firms; instead, they raise share prices directly, rewarding the selling of stock. From 2003 to 2012 , the firms that make up the S\&P 500 spent $54 \%$ of net income on buybacks ( $\$ 2.4$ trillion). ${ }^{88}$ This directly benefits the shareholders who sell stock at the higher prices, and corporate executives whose pay is largely stock-based. ${ }^{89}$ This activity is largely confined to the largest American firms, and examples from among America's top name brands abound. Investigating McDonald's, a study by William Lazonick, Matt Hopkins, and Ken Jacobson shows how the iconic American firm expended \$29.4 billion on buybacks from 2005 to 2014, which equated to $67 \%$ of net income. ${ }^{90}$ McDonald's, like many firms, conducts buybacks even when the stock price is relatively high, which is a further waste of corporate cash. $^{91}$ In 2017, Walmart announced a new \$20 billion stock buyback program, following years of billion-dollar buyback investments, even as its share price was up $17 \%$ last year. ${ }^{92}$ In the words of William Lazonick, as firms shifted to "favoring value extraction over value creation, this approach has contributed to employment instability and income inequality." $" 93$

Regulatory shifts have also contributed to the rise in stock buybacks. Stock buybacks opened up companies to liability for insider trading by the Securities and Exchange Commission (SEC) until 1982, when adoption of a "safe harbor" rule protected the practice from accusations of stock-price manipulation by the SEC as long as companies followed a set of basic rules governing timing and volume. Before the safe harbor was instituted, buybacks were near zero. According to William Lazonick,

Consider the 449 companies in the S\&P 500 index that were publicly listed from 2003 through 2012. During that period those companies used $54 \%$ of their earnings - a total of $\$ 2.4$ trillion - to buy back their own stock, almost all through purchases on the open market. Dividends absorbed an additional $37 \%$ of their earnings. That left very little for investments in productive capabilities or higher incomes for employees. ${ }^{94}$

\footnotetext{
88. Profits Without Prosperity, supra note 8.

89. Id.

90. Burger Buyback, supra note 74.

91. Id.

92. Joe Ciolli, Walmart Is Using the Oldest Trick in the Book to Boost its Stock Price, BuS. INSIDER (Oct. 10, 2017, 8:27 AM), http://www.businessinsider.com/walmart-stock-price-20-billionbuyback-announcement-2017-10.

93. Profits Without Prosperity, supra note 8.

94. Id.
} 
Companies repurchase shares in order to drive up earnings per share (EPS) by reducing the total shares on the market. ${ }^{95}$ The practice is seen as a more tax-efficient way to return capital to shareholders than declaring dividends. ${ }^{96}$

Section 9(a)(2) of the Securities Exchange Act of 1934 (the "Exchange Act") prohibit such fraudulent and manipulative practices in connection with an issuer's (or "affiliated purchaser's") purchase of the issuer's own securities. ${ }^{97}$ Rule 10b-18 allowed companies to put in place stock buyback programs ${ }^{98}$ and carry them out after approval by the board of directors, and set up a non-exclusive safe harbor against allegations of market manipulation under Section 9(a)(2) and Rule 10b-5 solely by reason of the manner, timing, price, and volume of the repurchases. ${ }^{99}$ In order to qualify for the safe harbor, the repurchase program, whether conducted directly by the company or by a broker-dealer, must meet all of the conditions outlined in the rule concerning the manner of purchase, timing of the purchase, volume level, and price. ${ }^{100}$ The safe harbor conditions apply daily, and a failure to meet any one of the four conditions eliminates the safe harbor for all purchases made that day. ${ }^{101}$ However, since disclosure is only made quarterly, in practice, unless purchases for the quarter totaled more than the aggregate of the allowed daily amount for the time period, there is no way for the SEC to determine whether the safe harbor rules have been violated.

Share repurchase programs should be disclosed before they are commenced, though no set disclosure period is required. Disclosure plans

95. Id.

96. Id.

97. Securities Exchange Act of 1934, 15 U.S.C. § 78i(a)(2) (2012).

98. 17 C.F.R. $\S 240.10$ b-18 (2017). Rule 10b5-1 trading plans allow for a firm to provide instructions to a broker to effect repurchases at a later date, as a way to establish an affirmative defense to a claim that it was aware of material non-public information when any such repurchases are then affected. $I d$. $\S 240.10 \mathrm{~b} 5-1$. Rule $10 \mathrm{~b} 5-1$ plans can operate side-by-side with discretionary plans. Id.

99. Rule 10b-18 does not protect against other types of violations of the Exchange Act. For example, the following are not covered by the safe harbor: purchases made based on material nonpublic information; purchases made as part of a plan or scheme to evade federal securities laws; certain types of repurchases, such as those part of a tender offer (which are subject to requirements under Rule $13 \mathrm{e}-4$ of the Exchange Act); those made as part of an employee plan; purchases of fractional security interests; purchases made during the period starting at the public announcement of a merger, acquisition or similar transaction involving a recapitalization, and ending at the earlier of the completion of such transaction or the vote by target shareholders; and going private transactions, when the purchase is intended to or reasonably likely to cause the company's common stock to be held by fewer than 300 persons or no longer listed on an exchange (as governed under Rule 13e-3). See id. $\S \S$ 240.10b-18, 240.13e-3, 240-13e4. The safe harbor also does not apply to purchases other than common stock (or an equivalent interest) or purchases made outside of the United States. See id.

100. Id. § 240.10b-18(b)(1)-(4).

101. Id. 
must include the time period for the program, the maximum number of shares proposed to be acquired or the maximum amount of funds to be expended, the objective of the acquisition of shares, any plan or proposal relating to the disposition of shares to be purchased, and any indication of how the purchase will be made. ${ }^{102}$ Disclosure can be made through a Form $10-\mathrm{Q},{ }^{103}$ Form $10-\mathrm{K} ;{ }^{104}$ press release, or Form 8-K. ${ }^{105}$ Disclosure of all issuer repurchases (regardless of whether they fall under the safe harbor) is required in quarterly reports under Regulations $\mathrm{S}-\mathrm{K}^{106}$ and S-B under the Exchange Act and the Investment Company Act of $1940,{ }^{107}$ though the reporting is done per month, whether they are conducted through openmarket purchases or private transactions. ${ }^{108}$ Companies report the total number of shares purchased, the price per share, and the proportion of the previously announced buyback program that has been accomplished at the time of the report. ${ }^{109}$

\section{FINANCIALIZATION AND LABOR MARKETS}

In the era of increased financialization, the ability of workers to bargain for a greater share of firm profits has eroded. The increased pressure from financial markets to keep share prices high and avoid hostile takeovers resulted in the top job of corporate executives shifting from managing rising sales to managing rising share price. This led not only to pressure to keep wages from rising, but to a fissured workplace as executives pushed to locate increasing proportions of nonprofessional workers outside the firm, whether through subcontracting or outsourcing. ${ }^{110}$ In other words, there is simply less availability for employee compensation, as profit must flow out to shareholders and creditors. This has long-term consequences for companies, as it

\footnotetext{
102. See id. § 229.703; see also Form N-CSR, SeC. AND EXChange Commission, https://www.sec.gov/files/formn-csr.pdf (last visited Mar. 17, 2018) (Item 8); Form 10-K, SEC. AND EXCHANGE COMMISSION, https://www.sec.gov/files/form10-k.pdf (last visited Mar. 17, 2018) (Item 5(c)); Form 10-Q, SEC. AND ExCHANGE COMMISSION, https://www.sec.gov/files/form10-q.pdf (last visited Mar. 17, 2018) (Item 2(e)); Form 20-F, SEC. AND EXChANGE COMMISSION https://www.sec.gov/files/form20-f.pdf) (last visited Mar. 17, 2018) (Item 16(E)).

103. Form 10-Q, supra note 102.

104. Form 10-K, supra note 102.

105. Form 8-K, SEC. AND EXCHANGE COMMISSION, https://www.sec.gov/files/form8-k.pdf (last visited Mar. 17, 2018).

106. 17 C.F.R. $\S \$ 229.10$ et seq. (2017).

107. 15 U.S.C. $\S \S 80 \mathrm{a}-1$ et seq. (2012).

108. Id. § 80a-29 (addressing the reporting requirement).

109. See supra notes 103-05.

110. See generally WeIL, supra note 26; VANISHING AMERICAN CORPORATION, supra note 22.
} 
potentially leads to declines in skill level and difficulties in improving the productivity of labor, especially when greater fissuring of the workplace occurs. The increasing share of profit earned off of financial assets also means that workers may be needed less, as firms make money off of financial activity rather than their traditional function. Finally, because executives have been transformed into shareholders themselves, their incentive to prioritize share price over productivity growth is personal. While companies may claim that increased compensation for employees is out of reach, the large-scale use of corporate profits for financial purposes debunks that claim.

Several authors look at the correlation between rising buybacks and declining wages, showing that corporate funds going to buybacks could be redeployed to raise wages. ${ }^{111}$ The scale is startling: As Catherine Ruetschlin and Amy Traub show, rather than spending $\$ 6.6$ billion on stock buybacks in 2013, Walmart could have raised the wages of its 825,000 frontline employees by $\$ 5.13$ per hour if it had chosen to invest in its workers. ${ }^{112}$ William Lazonick shows that while McDonald's conducted the buyback program described above, it paid the 90,000 US workers that it directly employs one dollar over the legal minimum wage, bringing the average wage to $\$ 9.90$ per hour. ${ }^{113}$

Ken-Hou Lin documents how the rise in financial asset-holding, the substitution of corporate debt for equity, and shareholder value orientation impacts employment size, and specifically considers the disparate effects among different occupational groups: production employees, service employees, and professional and management employees. ${ }^{114} \mathrm{He}$ finds that the increase in financial assets leads to a long-run significant decline in the blue-collar production workforce (whereas there is a positive effect on managerial, professional, and service employment). ${ }^{115}$ Lin also studies how the increased dependence on debt and its substitution for equity generates a rising pressure to pay interest before workers' claims can be considered; this behavior also amplifies the need to reduce the workforce during downturns, when creditors still need to be paid. ${ }^{116}$ His empirical

111. See generally Burger Buyback, supra note 74; Catherine Ruetschlin \& Amy Traub, A Higher Wage Is Possible at Walmart, DĒMOS 2 (2014), http://www.demos.org/sites/default/files/publications/ AHigherWageIsPossible.pdf (explaining how investors that focus on long-term performance "would benefit from reallocating resources to human capital management. ...”).

112. Ruetschlin \& Traub, supra note 112, at 2.

113. Burger Buyback, supra note 74, at 12.

114. See generally Lin, supra note 53.

115. Id. at $981-83$.

116. Id. at $977-78$. 
investigation shows that both rising debt and rising returns to shareholders have long-run negative effects on all occupational types. ${ }^{117}$ Interestingly, the debt ratio has a weaker impact on service employment than on the bluecollar production workforce, whereas the negative effect of shareholder rewards is strongest vis-à-vis service employment. ${ }^{118}$ Lin also finds that the financialization trends themselves, and their impact on employment size, rose throughout the last few decades. ${ }^{119}$

Ken-Hou Lin and Donald Tomaskovic-Devey investigate the impact of rising corporate financialization and income inequality, finding that increased earnings from financial activity is associated with a falling labor share, increased compensation of top executives, and increased earnings dispersion among workers. ${ }^{120}$ They find that:

[T] he financialization of the U.S. economy restructured social relations and income dynamics in the rest of the economy. We believe that firms' increasing reliance on financial, rather than production, income decoupled the generation of surplus from production and sales, strengthening owners' and elite workers' negotiating power against other workers. The result was an incremental exclusion of the general workforce from revenue-generating and compensation-setting processes. ${ }^{121}$

Notably, their research shows that financialization had an impact on labor outcomes comparable with the more common explanations for increased income inequality, including globalization, technological change, capital investment, and declining rates of unionization. ${ }^{122}$ Their study also conducted a counterfactual analysis, fixing the level of corporate financialization at its 1970 level and examining the difference between the observed and counterfactual trend. ${ }^{123}$ The contrast shows that financialization accounted for approximately $58 \%$ of the decline in labor's share of profits between 1970 and 2008. ${ }^{124}$ The counterfactual analysis shows a lesser but still positive impact on the growth of officers' share of compensation (9.6\%) and growth in earnings dispersion between 1970 and $2008(10.2 \%){ }^{125}$

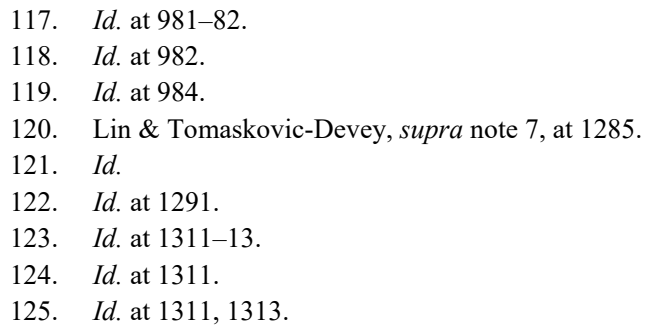


Petra Dünhaupt also examines the effect of both strands of corporate financialization on labor's share of income, measuring the "distributional conflict" between firms and shareholders on the one hand and wage and salary earners on the other. ${ }^{126}$ She uses net interest and dividend payments as a share of the capital stock of the business sector as the proxy for financialization and finds a positive relationship between the increase of such payments and the decline of the share of national income that goes to wages. ${ }^{127}$ Rising shareholder value orientation is measured as increased net interest and net dividend payments as a share of the capital stock of the business sector. ${ }^{128}$ She examines results for thirteen countries from 1986 to 2007 and finds that the share of retained profits declined along with the labor share, while dividend and interest payments were rising - pointing to increased corporate financialization as a causal factor in the decline of the labor share. ${ }^{129}$

\section{CORPORATE FINANCIALIZATION AND PRODUCTIVE INVESTMENT}

Rising corporate financialization has not only weakened the labor market, it has also left less firm profit available for productive investment. In an important pair of papers, Germán Gutiérrez and Thomas Philippon document how declining investment relative to profit began in the $2000 \mathrm{~s},{ }^{130}$ largely explained by increasing market power ${ }^{131}$ and common ownership within industries. Firms also exhibit a disproportionate amount of short-termism and tightened corporate governance. ${ }^{132}$ Specifically, they find that firms that invest less, despite high profits, spend a

126. Petra Dünhaupt, The Effect of Financialization on Labor's Share of Income 1 (Inst. for Int'1 Political Econ. Berlin, Working Paper No. 17/2013, 2013), http://www.ipe-berlin.org/fileadmin/ downloads/working_paper/ipe_working_paper_17.pdf.

127. Id.

128. Id. at 11 .

129. Id. at $12,17-18$.

130. See generally Investment-less Growth, supra note 1; Germán Gutiérrez \& Thomas Philippon, Declining Competition and Investment in the U.S. (Nat'l Bureau of Econ. Research, Working Paper 23583, 2017) [hereinafter Declining Competition and Investment], https://www8.gsb.columbia.edu/faculty-research/sites/facultyresearch/files/finance/Macro\%20Lunch/IK_Comp_v1.pdf .

131. Marshall Steinbaum, Eric Harris Bernstein \& John Sturm define market power as the ability to skew market outcomes in a participant's own interest without creating shared value or serving the public good. See generally MARShall SteINBAUM, ERIC HARRIS BERNSTEIN \& JOHN STURM, POWERLESS: How Lax Antitrust and CONCENTRATED Market POWER Rig THE ECONOMY Against AMERican Workers, CONSUMERs, AND COMMUnities (Roosevelt Inst., 2018), http://rooseveltinstitute.org/wp-content/uploads/2018/03/Powerless.pdf.

132. Id. at 5 . 
disproportionate amount of available cash flow on stock repurchases. ${ }^{133}$ Investment has not fallen because profit has fallen; they show that the average ratio of net investment to net operating surplus has fallen from an average of $20 \%$ between 1959 and 2001 to $10 \%$ between 2002 and $2015 .{ }^{134}$ In other words, despite available cash, "industries with less competition invest . . less," 135 while governance prioritizes buybacks over productive investment. Gutierrez and Philippon also examined other common explanations for low investment, but found those based on financial frictions and globalization to be less persuasive. ${ }^{136}$

J.W. Mason also provides evidence of the break in the link between corporate cash flow and borrowing and productive investment, showing that since the 1980s, firms largely "borrow to enrich their investors in the short-run."137 This phenomenon reached its zenith in mid-2007, just before the financial crisis, when aggregate payouts actually exceeded aggregate investment. ${ }^{138}$ Mason shows a dramatic shift over time: "In the 1960 s and 1970s, an additional dollar of earnings or borrowing was associated with about a forty-cent increase in investment."139 This ratio has been less than ten cents of each borrowed dollar since the 1980s. ${ }^{140}$ At the same time, shareholder payouts nearly doubled. ${ }^{141}$ Mason shows that "the net flow of funds from financial markets to the corporate sector" did not shift before and after the Great Recession, and the decline in investment cannot be explained by tightening credit conditions. ${ }^{142}$ As he explains, "finance is no longer an instrument for getting money into productive businesses, but instead for getting money out of them." 143

Demonstrating the importance of productive investment in one critical industry, William Lazonick, Matt Hopkins, and Ken Jacobson examine the financialization of the pharmaceutical industry, concluding that increased financialization means that profits are not invested in potentially lifesaving 
innovations in new drugs. ${ }^{144}$ Firms in the pharmaceutical sector allocate a disproportionate share of profits to share repurchase programs, enriching top executives along the way, while arguing against price regulation in the name of retaining high levels of profits to invest in innovation. ${ }^{145}$ They found that the eighteen drug companies in the S\&P 500 Index distributed $99 \%$ of profits to shareholders from 2006 to 2015, distributed as 50\% buybacks and $49 \%$ dividends. ${ }^{146}$ This translates to $\$ 261$ billion spent on buybacks over the decades, unevenly divided among the eighteen firms. ${ }^{147}$ Meanwhile, investment in R\&D was only $16 \%$ of total revenue. ${ }^{148}$

Leila Davis conducted a firm-level analysis of the constraint on fixed investment from increased flows to the financial sector. ${ }^{149}$ She defines financialization as an "increasingly complex" relationship between NFCs and the financial sector; ${ }^{150}$ and she shows the rise of financialization through the increasing share of financial assets relative to both sales and shifts in external financing (increasing indebtedness), especially for large firms, which leads to declining investment. ${ }^{151}$ Specifically, she shows that for large firms, total financial assets increased from $29.8 \%$ of sales in 1971 to $47.2 \%$ in 2011 , while fixed capital declined from $52.4 \%$ to $43.9 \%$ of sales. ${ }^{152}$ Her firm-level data set allows for a more specific demonstration of the shifting asset mix by disaggregating different assets and separating cash and short-term investments, current receivables, advances, and "other" financial assets. ${ }^{153}$ This shows that liquid capital increased 4.2\% for large firms, while "other" capital increased 8.6\%. ${ }^{154}$ She suggests that the move into "other" financial assets held by large NFCs may reveal a shift into providing financial services, such as car loans or store credit cards. ${ }^{155}$

\footnotetext{
144. See generally William Lazonick, Matt Hopkins, Ken Jacobson, Mustafa Erdem Sakinç \& Öner Tulum, US Pharma's Financialized Business Model (Inst. for New Econ. Thinking, Working Paper No. 60, 2017), https://www.ineteconomics.org/uploads/papers/WP_60-Lazonick-et-al-USPharma-Business-Model.pdf.

145. Id. at 2 .

146. Id. at 3 .

147. See id. at 4 .

148. Id.

149. See generally Nonfinancial Corporation, supra note 7. Fixed investment refers to investment in physical capital and/or assets and technology (in contrast to investments in labor and financial assets).

150. Id. at 2 .

151. Id. at 4 .

152. Id. at 4 .

153. See id. at 4

154. Id. at 4 .

155. Id. at 18 .
} 
Davis posits that it is critical to examine the purpose of increased financial profits in order to more fully understand the impact on fixed investment. ${ }^{156}$ Investment decisions rely on the value of fixed investment as well as decisions on how to finance investments; both have shifted in the last several decades due to new norms of corporate governance and rising firm-level volatility. ${ }^{157}$ She finds that rising shareholder value maximization is associated with declining fixed investment in large firms as the pressure of short-termism drives reallocation. ${ }^{158}$ For the largest firms, a 1-standard-deviation increase in average industry-level repurchases is associated with a .14-standard-deviation decline in investment. ${ }^{159}$ In contrast, she finds that "the stock of financial assets is found to have a positive and robust relationship to fixed investment in both the short-term and the long-run in most specifications." ${ }^{160}$ This is consistent with her explanation that "for given expected returns, firms hold both fixed and financial assets, and investment actually increases if the stock of financial assets rises above the desired level."161 Especially for large firms, the financial profit rate is positively correlated with investment, suggesting "large firms generate complementarities between financial profits and the nonfinancial components of their business that are not captured by smaller firms." 162 This movement into rising investment as the profit rate rises shows how certain types of rising financial assets can increase demand for the firm's nonfinancial profits, thereby supporting, rather than hindering, fixed investment.

Additional studies also examine the relationship between financial profit and investment. Özgür Orhangazi outlines a model specifying two flows of financialization-income earned off of investment in financial assets and financial payouts - and examines each with respect to corporate investment. ${ }^{163}$ He tests the two effects on a large sample of firms over the three decades from 1973 to $2003 .{ }^{164} \mathrm{He}$ finds, as above, that increased financial profit opportunities crowd out productive investment as managers chase higher short-term returns, and that increased payments to

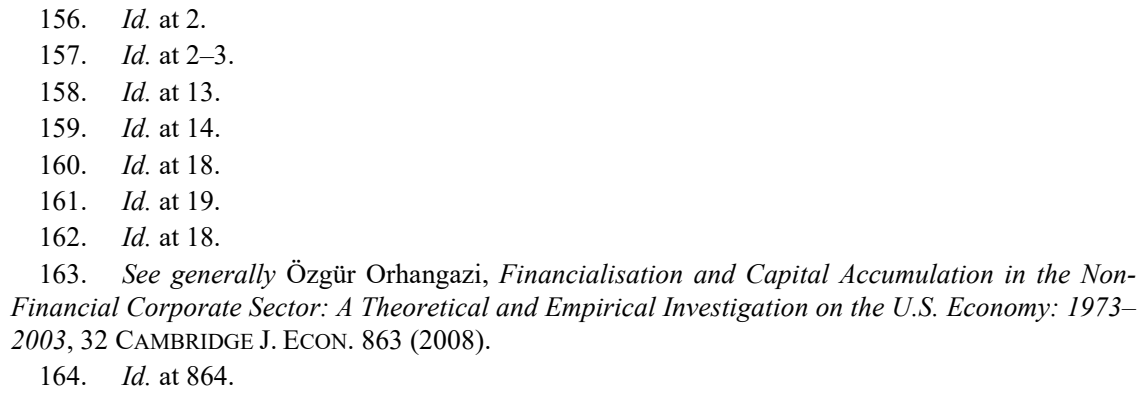


shareholders decrease available internal funds, while also increasing uncertainty. ${ }^{165}$ Like Davis, Orhangazi finds that the negative effects from increased financial profits is mainly felt by large corporations. ${ }^{166}$

\section{CONCLUSION}

As the financialization of the corporate sector continues, it is critical to understand that none of these shifts are inevitable: all result from policy choices that create incentives and opportunities for firms to increasingly act as financial actors. Therefore, along with implementing policies that raise the minimum wage through legislation and improve the bargaining power of wage-earners through unionization, it is critical to rewrite tax, corporate governance, and other public policies that have driven firms to financialize. America's working families, and future prosperity, depend on this reorientation.

165. Id.

166. Id. 